\title{
Molecular Cloning and Anti-fungal Effect of Endo- $\beta$-1,3-glucanase from Thermotoga maritima
}

\author{
Chang-Bin Woo, Hae-Na Kang, and Soo-Bok Lee
}

Received August 24, 2013; revised January 2, 2014; accepted January 8, 2014; published online August 31, 2014

(C) KoSFoST and Springer 2014

\begin{abstract}
A gene encoding an endo- $\beta-1,3$-glucanase from Thermotoga maritima MSB8 $(\operatorname{Tm} \beta \mathrm{G})$ was cloned and expressed in Escherichia coli. The purified enzyme produced various $\beta$-1,3-glucooligosaccharides from soluble laminarin, and mainly $\beta-1,3$-glucooligosaccharides smaller than laminaritetrose from insoluble curdlan. The optimum $\mathrm{pH}$ and temperature of the enzyme were 5.0 and $80^{\circ} \mathrm{C}$, respectively. $\operatorname{Tm} \beta \mathrm{G}$ inhibited the growth of Candida albicans, which indicates that the enzyme could potentially be used as an anti-fungal agent to control invasive infections.
\end{abstract}

Keywords: endo- $\beta$-1,3-glucanase, Thermotoga maritima, $\beta$-1,3-glucans, $\beta$-1,3-glucooligosaccharide, anti-fungal

\section{Introduction}

$\beta$-1,3-Glucan, a polysaccharide of $\beta$-(1,3)-linked glucose, is a major constituent of fungal, plant, and marine macroalgae. Laminarin and curdlan are two common $\beta$-1,3-glucans. Laminarin is a soluble storage polysaccharide mainly found in brown algae such as Laminaria spp. (1). Curdlan is usually a bacterial, water-insoluble linear $\beta-(13)$ homopolymer of D-glucose (2).

$\beta-1,3$-Glucanase can degrade $\beta-1,3$-linked glucan, which is major component of fungal and plant cell walls (3). The enzyme may thus help protect against fungal pathogens by hydrolyzing $\beta-1,3$-glucan, a major cell wall component, which also functions in cell differentiation (4). $\beta-1,3-$ Glucanases in bacteria belong to $\mathrm{GH} 16$, members of which degrade $\beta$-1,3-glucan polymer as substrate for

Chang-Bin Woo, Hae-Na Kang, Soo-Bok Lee $(\triangle)$

Department of Food and Nutrition, Brain Korea 21 Project, Yonsei University, Seoul 120-749, Korea

Tel: +82-2-2123-3124; Fax: +82-2-312-5229

E-mail: soobok@yonsei.ac.kr assimilation. Endo- $\beta-1,3$-glucanase can be used in the industrial production of yeast extract (5) and soluble $\beta-1,3-$ glucan, which is a potential immunomodulator (6). Endo$\beta$-1,3-glucanase can also serve as a biocontrol agent for protecting plants from fungal invasion. Extensive hydrolysis of the $\beta$-glucan polymer of the fungal cell wall may play a role in fungal cell lysis, allowing for the control of fungal diseases (7). For example, growth of Candida sp. was reported to be prohibited by endo- $\beta$-1,3-glucanases from Pichia anomala and Paenibacillus sp. (8). C. albicans is a dimorphic fungus that can switch from a unicellular yeast form to one characterized by mycelial hyphae, thereby enhancing its virulence as a fungal pathogen. It is a widespread pathogenic yeast-like fungus that has increased in importance because it causes disease in immunocompromised humans $(9,10)$. The growth of $C$. albicans is reportedly inhibited by endo- $\beta-1,3$-glucanase (11). Thus, endo- $\beta$-1,3-glucanases can be utilized industrially to protect foods and plants from fungal invasion $(11,12)$. Endo- $\beta$-1,3-glucanases have also been described in hyperthermophilic bacteria, including Rhodothermus marinus (13), Thermotoga neapolitana (14), and others. The $\beta-1,3-$ glucooligosaccharide pattern in a complete hydrolysis is characteristic for a given enzyme.

In this study, the gene encoding an endo- $\beta$-1,3-glucanase from T. maritima was cloned and expressed in Escherichia coli. The biochemical properties and anti-fungal activity of the purified enzyme against the disease-causing fungus, $C$. albicans, were investigated.

\section{Materials and Methods}

Strains, plasmids, and chemicals Genomic DNA of $T$. maritima MSB8 was purchased from the American Type Culture Collection. E. coli strain BL 21 (DE3) was used as 
a host for gene manipulation and expression of the recombinant protein. Plasmid pGEX-4T-1 vector was used as an expression vector, containing the tac promoter, the glutathione $\mathrm{S}$ transferase (GST) tag, and ampicillin resistance gene. The $E$. coli transformants were cultured at $37^{\circ} \mathrm{C}$ in Luria-Bertani (LB) medium supplemented with ampicillin $(100 \mu \mathrm{g} / \mathrm{mL})$. C. albicans were purchased from the Korean Culture Center of Microorganisms (KCCM). All other chemicals used were of reagent grade.

PCR cloning and expression of endo- $\beta$-1,3-glucanase The gene for the endo- $\beta-1,3$-glucanase from $T$. maritima MSB8 (TmßG, Q9WXN1) was amplified using the genomic DNA as a template with PCR using i-StarTaq DNA Polymerase (iNtRON Biotechnology, Seongnam, Korea). Oligonucleotide primers for the 5- and 3-flanking ends of the gene were 5-ATGAAAAGGGGATCCATGATGAGC AGGCTGGTT-3 (forward) and 5-CACCGGGGAGTCGA CTCATTGAGGGCTCACCGT-3 (reverse), and contained BamHI and Sall restriction sites, respectively (underline). The 1.9 kb PCR-amplified DNA fragment was subsequently digested with BamHI and SalI, and thereafter ligated into the expression vector pGEX4T1 to construct pGEX4T1$\mathrm{Tm} \beta \mathrm{G}$. The final construct was transformed into competent E. coli BL21(DE3).

Purification and assay of the recombinant enzyme Tm $\beta G$ was purified according to a previously-described procedure (15). The recombinant GST-fusion enzyme in the supernatant after centrifugation $\left(7,000 \times g, 10 \mathrm{~min}, 4^{\circ} \mathrm{C}\right)$ was purified by Glutathione Sepharose 4 Fast Flow (FF) affinity column chromatography (GE Healthcare BioSciences, Sweden), in which the protein was eluted with $50 \mathrm{mM}$ Tris- $\mathrm{HCl}(\mathrm{pH} 8.0)$ containing $40 \mathrm{mM}$ reduced glutathione. The eluted fractions were pooled and treated with thrombin protease ( $40 \mathrm{U} / \mathrm{mg}$ protein) for $24 \mathrm{~h}$ at $25^{\circ} \mathrm{C}$. After dialysis, the GST portion of the fusion protein was removed through the Glutathione Sepharose 4 FF column, and the eluted solution was applied to a Q-Sepharose FF column (Hi-Load 16/10) equilibrated with $20 \mathrm{mM}$ Tris$\mathrm{HCl}(\mathrm{pH}$ 7.5). This solution was then eluted with a linear $\mathrm{NaCl}$ gradient $(0.0-1.0 \mathrm{M})$ in the same buffer to separate the GST and the thrombin protease from free $\operatorname{Tm} \beta G$ and dialyzed.

Tm $\beta$ G activity was determined in sodium acetate buffer $(\mathrm{pH}$ 5.0) at room temperature by measuring hydrolysis of laminarin (1\%) using the copper-bicinchoninate method at $560 \mathrm{~nm}$ (16). The reaction was stopped by adding $0.1 \mathrm{~N}$ $\mathrm{HCl}$. The hydrolytic reactions catalyzed by $\operatorname{Tm} \beta \mathrm{G}$ were analyzed TLC and high performance anion exchange chromatography (HPAEC). TLC was carried out according to a previously-described procedure on Whatman $\mathrm{K} 5 \mathrm{~F}$ silica gel plates (Whatman, Kent, UK) with the solvent system of ethyl acetate:acetic acid:water (3/2/1, v/v/v) (17). HPAEC was also employed to analyze the reaction product on a Dionex CarboPac PA1 column $(250 \times 4 \mathrm{~mm}$; Sunnyvale, CA, USA) with a gradient of $120 \mathrm{mM}$ sodium acetate in $150 \mathrm{mM} \mathrm{NaOH}$ (solvent $\mathrm{A}$ ) and $600 \mathrm{mM}$ sodium acetate in $150 \mathrm{mM} \mathrm{NaOH}$ at a flow rate of $1.0 \mathrm{~mL} / \mathrm{min}$.

Effects of $\mathrm{pH}$, temperature, and chemicals on enzyme activity To determine the optimal $\mathrm{pH}$ of the enzyme, the activity was measured in the following $50 \mathrm{mM}$ buffers at room temperature: sodium acetate ( $\mathrm{pH} 2.0$ to 5.0), sodium citrate ( $\mathrm{pH} 5.0$ to 6.0 ), sodium phosphate ( $\mathrm{pH} 6.5$ and 7.0), Tris-HCl (pH 8.0 to 9.0), and glycine- $\mathrm{NaOH}$ (pH 10.0 to 11.0). The optimal temperature of the enzyme was investigated in a range of 25 to $90^{\circ} \mathrm{C}$ in $50 \mathrm{mM}$ sodium acetate buffer (pH 5.0). The effects of metal ions $\left(\mathrm{CaCl}_{2}, \mathrm{CuCl}_{2}, \mathrm{MgCl}_{2}\right.$, and $\mathrm{MnCl}_{2}$ ) and organic solvents [dimethylsulfoxide (DMSO), methanol, and ethanol] on the enzyme activity were also examined. The enzyme was added and mixed in the absence and presence of $10 \mathrm{mM}$ cations or a $10 \%(\mathrm{v} / \mathrm{v})$ organic solvent in $50 \mathrm{mM}$ sodium acetate buffer (pH 5.0), and immediately after an appropriate aliquot was taken, the relative activity was measured at room temperature.

Anti-fungal activities of $\mathbf{T m} \beta \mathbf{G}$ C. albicans (KCCM 11282) was cultivated overnight in $5 \mathrm{~mL}$ liquid medium containing $0.3 \%$ yeast extract, $0.3 \%$ malt extract, $1 \%$ dextrose, and $0.5 \%$ peptone at $37^{\circ} \mathrm{C}$. After centrifugation $\left(7,000 \times \mathrm{g}, 10 \mathrm{~min}, 4^{\circ} \mathrm{C}\right)$, the cell pellets were harvested and resuspended in $1 \mathrm{~mL}$ sterile distilled water (DW) at 0.5 optical density (OD). The diluted fungus suspension and the purified enzyme were incubated at various concentration of the enzyme ranging from $0.1-0.5 \mathrm{mg} / \mathrm{mL}$ in $50 \mathrm{mM}$ sodium citrate buffer $(\mathrm{pH} 5.0)$ at $30^{\circ} \mathrm{C}(3 \mathrm{~h})$, and the mixture was then spread out on an agar plate. The plate was incubated at $30^{\circ} \mathrm{C}$ for $20 \mathrm{~h}$.

\section{Results and Discussion}

Biochemical properties of endo- $\beta$-1,3-glucanase $(\operatorname{Tm} \beta G)$ The open reading frame $(1.9 \mathrm{~kb})$ of $\mathrm{Tm} \beta \mathrm{G}$ from $T$. maritima MSB8 encodes a single polypeptide of 642 amino acid residues. The Tm $\beta \mathrm{G}$ gene was expressed in E. coli as a glutathione S-transferase (GST)-tagged protein with a molecular weight of approximately $99 \mathrm{kDa}$. The GST tag $(26 \mathrm{kDa})$ was completely released by thrombin treatment. Tm $\beta \mathrm{G}$ produced broad but distinct hydrolyzed product profiles when $\beta$-glucans such as laminarin and curdlan were used as substrates. When $\operatorname{Tm} \beta \mathrm{G}$ was reacted with laminarin, hydrolyzed products in the size range from glucose to $\beta-1,3$-glucooligosaccharides with degree of polymerization (DP)8 were disproportionately represented 

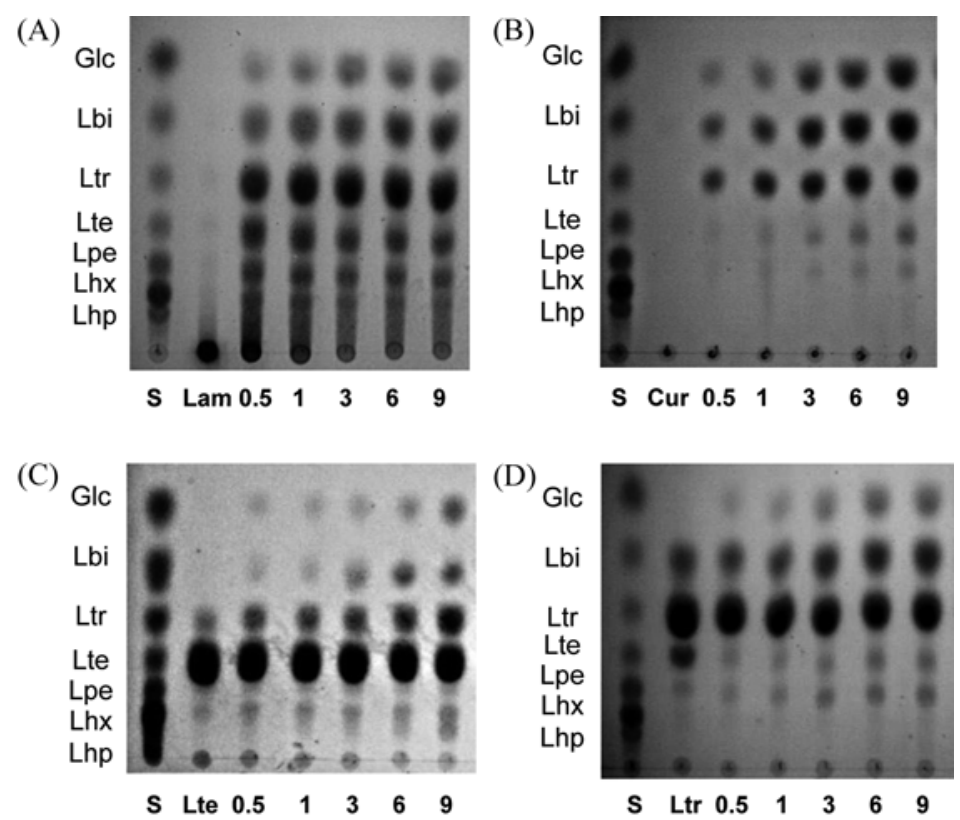

Fig. 1. TLC analysis of Thermotoga maritima MSB8 $(\mathbf{T m} \beta \mathrm{G})$ reaction with $\beta$-glucans at $\mathbf{5 0} 0^{\circ} \mathrm{C}$. Reactions of $\mathrm{Tm} \beta \mathrm{G}$ with $1 \%$ laminarin (A), with $1 \%$ curdlan (B), with $1 \%$ laminaritetraose (C), and with $1 \%$ laminaritriose. The reactions were carried out with $\mathrm{Tm} \beta \mathrm{G}$ at $0.1 \mathrm{mg} / \mathrm{mL}$ and $\beta$-glucans in $50 \mathrm{mM}$ sodium citrate buffer ( $\mathrm{pH} 5.0)$. Lane $\mathrm{S}$, standard $\beta$-1,3-glucooligosaccharides; lanes 0.5 , 1 , 3, 6, 9, reaction times of Tm $\beta \mathrm{G}$; Cur, curdlan; Lam, laminarin; Lte, laminaritetraose; Ltr, laminaritriose

(Fig. 1A). When the enzyme was reacted with curdlan, hydrolyzed products mainly ranged in size from glucose to laminaritriose (Fig. 1B). When laminaritriose and laminaritetrose were used as substrates, transglycosylation activity was detected as well as hydrolysis, as evidenced by the production of $\beta-1,3$-glucooligosaccharide products with $\mathrm{DP}>3$ or 4 , such as laminaritetrose, laminaripentaose, and laminarihexaose (Fig. 1C, 1D). The $\beta$-1,4-glucans carboxyl methyl cellulose (CMC) and cellobiose, and the $\alpha-1,4-$ glucan amylose could not be hydrolyzed by the enzyme to any appreciable extent. Only $\beta$-1,3-glucans like laminarin were efficiently degraded. This resembles the behavior of other hyperthermophilic endo- $\beta$-1,3-glucanases (laminarinases) from Pyrococcus furiosus and T. petrophila $(18,19)$. The optimum temperature and $\mathrm{pH}$ of $\mathrm{Tm} \beta \mathrm{G}$ were determined to be approximately $80^{\circ} \mathrm{C}$ and $\mathrm{pH} 5.0$, respectively (Fig. 2). The enzyme was thermostable, as expected of an enzyme that originated from a hyperthermophilic bacterium. In addition, the $\beta-1,3$-glucanase activity of the enzyme was increased approximately 1.5 -2-fold by the presence (10 $\mathrm{mM})$ of $\mathrm{Ca}^{2+}, \mathrm{Mg}^{2+}$, or $\mathrm{Na}^{+}$ions. It has been reported that the enzyme contains $\mathrm{Ca}^{2+}$ binding sites and that these play a role in its thermoactivity (18). The enzyme's activity was not substantially affected by $\mathrm{Cu}^{2+}$ or $\mathrm{Zn}^{2+}$, but was significantly decreased by $\mathrm{Co}^{2+}$ and $\mathrm{Mn}^{2+}$. The enzyme's activity in the presence of $10 \%$ of the organic solvents methanol, ethanol, and DMSO was 52, 34, and $16 \%$ of its activity in their absence, respectively.

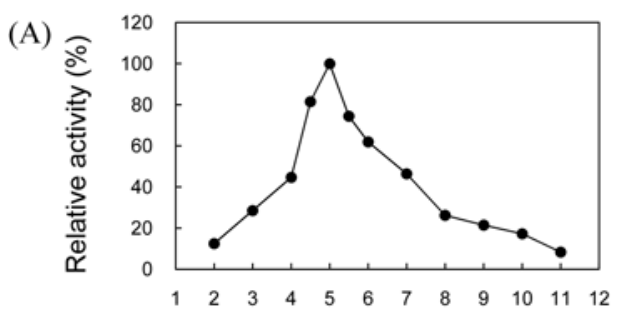

$\mathrm{pH}$

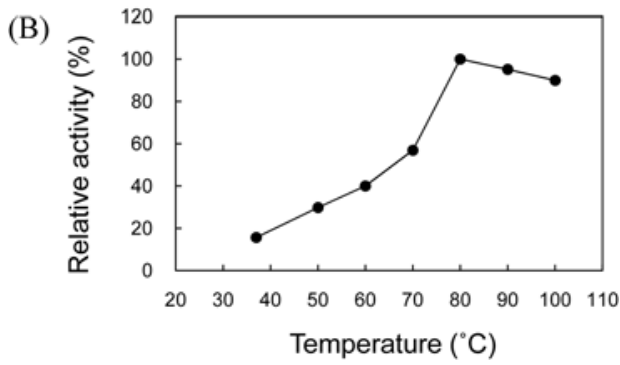

Fig. 2. Effects of $\mathrm{pH}$ and temperature on the relative activity of TmßG (A) Optimum pH (B) Optimum temperature. The hydrolysis of laminarin $(1 \%)$ was determined at $50^{\circ} \mathrm{C}$. The enzyme $(1 \mathrm{mg} / \mathrm{mL})$ was pre-incubated in various $\mathrm{pHs}$ for $90 \mathrm{~min}$ at $25^{\circ} \mathrm{C}$.

Anti-fungal activities of endo- $\beta-1,3$-glucanase Endo- $\beta$ 1,3 -glucanase can hydrolyze and degrade the $\beta-1,3-$ polysaccharides of fungal cell walls, inhibiting the growth of pathogenic fungi (3). We observed that the growth of C. albicans was substantially inhibited by $\operatorname{Tm} \beta \mathrm{G}$ in a concentration-dependent manner (Fig. 3). Approximately 


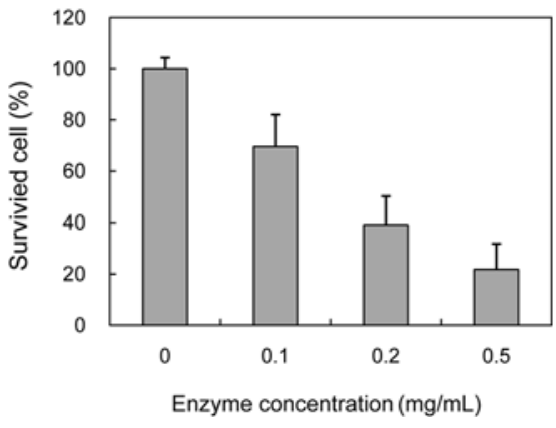

Fig. 3. The growth inhibition of $C$. albicans by various concentrations of $\mathbf{T m} \beta \mathbf{G}$. The enzyme reaction was incubated in $50 \mathrm{mM}$ sodium citrate buffer $(\mathrm{pH} 5.0)$ at $30^{\circ} \mathrm{C}$.

$60 \%$ of the growth of $C$. albicans was inhibited by $\operatorname{Tm} \beta \mathrm{G}$ at levels higher than $-200 \mu \mathrm{g} / \mathrm{mL}(-2.7 \mu \mathrm{M})$. Recently, endo$\beta-1,3$-glucanase from Paenibacillus sp. was reported to inhibit growth at approximately $0.3-1 \mu \mathrm{M}(11)$. Tm $\beta \mathrm{G}$ was clearly able to inhibit the growth of $C$. albicans, which pose serious health threat (12). This suggests that $\mathrm{Tm} \beta \mathrm{G}$ could potentially be used as a new thermostable anti-fungal agent with an improved safety profile.

In conclusion, $\operatorname{Tm} \beta \mathrm{G}$ can degrade $\beta$-1,3-glucan to produce various $\beta$-1,3-glucooligosaccharides from soluble laminarin and insoluble curdlan. $\operatorname{Tm} \beta \mathrm{G}$ also significantly inhibited the growth of $C$. albicans. Thus, $\operatorname{Tm} \beta \mathrm{G}$ is a thermostable anti-fungal $\beta$-1,3-glucanase with potential for use in food preservation.

Acknowledgments This research was supported by Basic Science Research Program through the National Research Foundation of Korea (NRF) Grant funded by the Ministry of Education, Science and Technology (2012R1A1A2005524).

Disclosure The authors declare no conflict of interest.

\section{References}

1. Alan TB, Chesters CGC. The biochemistry of laminarin and the nature of laminarinase. pp. 325-364. In: Advances in Enzymology and Related Areas of Molecular Biology. Meister A (ed). Jones Wiley \& Sons, Inc., Hoboken, NJ, USA (2009)

2. Grandpierrea C, Janssena H-G, Larocheb C, Michaudb P, Warrand J. Enzymatic and chemical degradation of curdlan targeting the production of $\beta-(13)$ oligoglucans. Carbohyd. Polym. 71: 277-286 (2008)

3. Errakhi R, Bouteau F, Lebrihi A, Barakate M. Evidences of biological control capacities of Streptomyces spp. against Sclerotium rolfsii responsible for damping-off disease in sugar beet (Beta vulgaris L.). World J. Microb. Biot. 23: 1503-1509 (2007)

4. Coutinho PM, Stam M, Blanc E, Henrissat B. Why are there so many carbohydrate-active enzyme-related genes in plants? Trends Plant Sci. 8: 563-565 (2003)

5. Ryan EM, Ward OP. Study of the effect of $\beta-1,3$-glucanase from Basidiomycete QM 806 on yeast extract production. Biotechnol. Lett. 7: 409-412 (1985)

6. Kim KH, Kim YW, Kim HB, Lee BJ, Lee DS. Anti-apoptotic activity of laminarin polysaccharides and their enzymatically hydrolyzed oligosaccharides from Laminaria japonica. Biotechnol. Lett. 28: 439-446 (2006)

7. Shi P, Yao G, Yang P, Li N, Luo H, Bai Y, Wang Y, Yao B. Cloning, characterization, and antifungal activity of an endo-1,3- $\beta$-Dglucanase from Streptomyces sp. S27. Appl. Microbiol. Biot. 85: 1483-1490 (2010)

8. Izgü F, Altinbay D, Türeli AE. In vitro susceptibilities of Candida spp. to panomycocin, a novel exo- $\beta-1,3$-glucanase isolated from Pichia anomala NCYC 434. Microbiol. Immunol. 51: 797-803 (2007)

9. Tayel AA, Moussa S, El-Tras WF, Knittel D, Opwis K, Schollmeyer E. Anticandidal action of fungal chitosan against Candida albicans. Int. J. Biol. Macromol. 47: 454-457 (2010)

10. Candiracci M, Citterio B, Piatti E. Antifungal activity of the honey flavonoid extract against Candida albicans. Food Chem. 131: 493499 (2012)

11. Cheng YM, Hong TY, Liu CC, Meng M. Cloning and functional characterization of a complex endo- $\beta$-1,3-glucanase from Paenibacillus sp. Appl. Microbiol. Biot. 81: 1051-1061 (2009)

12. Veiga-Crespo P, Ageitos JM, Poza M, Villa TG. Enzybiotics: A look to the future, recalling the past. J. Pharm. Sci. 96: 1917-1924 (2007)

13. Neustroev KN, Golubev AM, Sinnott ML, Borriss R, Krah M, Brumer III H, Eneyskaya EV, Shishlyannikov S, Shabalin KA, Peshechonov VT, Korolev VG, Kulminskaya AA. Transferase and hydrolytic activities of the laminarinase from Rhodothermus marinus and its M133A, M133C, and M133W mutants. Glycoconjugate J. 23: 501-511 (2006)

14. Zverlov VV, Volkov IY, Velikodvorskaya TV, Schwarz WH. Highly thermostable endo-1,3- $\beta$-glucanase (laminarinase) Lam A from Thermotoga neapolitana: Nucleotide sequence of the gene and characterization of the recombinant gene product. Microbiology 143: 1701-1708 (1997)

15. Ryu S-I, Kim J-E, Kim E-J, Chung S-K, Lee S-B. Catalytic reversibility of Pyrococcus horikoshii trehalose synthase: Efficient synthesis of several nucleoside diphosphate glucoses with enzyme recycling. Process Biochem. 46: 128-134 (2011)

16. Fox JD, Robyt JF. Miniaturization of three carbohydrate analyses using a microsample plate reader. Anal. Biochem. 195: 93-96 (1991)

17. Wu W-J, Park S-M, Ahn B-Y. Isolation and characterization of an antimicrobial substance from Bacillus subtilis BY08 antagonistic to Bacillus cereus and Listeria monocytogenes. Food Sci. Biotechnol. 22: 433-440 (2013)

18. Ilari A, Fiorillo A, Angelaccio S, Florio R, Chiaraluce R, van der Oost J, Consalvi V. Crystal structure of a family 16 endoglucanase from the hyperthermophile Pyrococcus furiosus- structural basis of substrate recognition. FEBS J. 276: 1048-1058 (2009)

19. Cotaa J, Alvareza TM, Citadinia AP, Santosb CR, Netoc MO, Oliveirab RR, Pastored GM, Rullera R, Pradee RA, Murakamib MT, Squina FM. Mode of operation and low-resolution structure of a multi-domain and hyperthermophilic endo- $\beta$-1,3-glucanase from Thermotoga petrophila. Biochem. Bioph. Res. Co. 406: 590-594 (2011) 